\title{
美国洛厄尔工业遗产价值共享机制的实践探索
}

\section{An Exploration on the Practice of the Lowell's Value-sharing Mechanism of the Industrial Heritage}

张琪

Zhang Qi

摘要：文章分析了美国工业遗产保护与城市复兴相结 合的洛厄尔保护实践案例, 归纳了基于价值共享理念 的遗产实践多边合作框架, 梳理了以整体化的要素识 别、多维化的价值阐释和互动化的保护利用, 达成弥 合多元社会, 实现地区认同, 经济社会复兴的实践原 则和方法。

Abstract: Based on the analysis of the outstanding industrial heritage conservation practice in Lowell, the US, this article tries to conclude the multilateral cooperation framework with the value-sharing concept. It generalizes the integrated recognition of the heritage elements, the multidimensional interpretation and presentation of the mixed value, and the interactive protective action, aiming to find out the practical principles and measures to bridge the pluralistic society, achieve the community identity and the economic and social revival.

关键词:工业遗产; 价值共享; 本体识别; 价值阐释; 保护实践

Keywords: Industrial Heritage; Value-sharing; Heritage Recognition; Interpretation and Presentation; Protective Practice
洛厄尔位于美国东北部新英格兰地区马萨诸塞州的梅里马克河流域, 市 域面积 $37.7 \mathrm{~km}^{2}$, 人口约 11.7 万 ${ }^{[1]}$ (图 1)。19 世纪运河建设及技术创新背景下, 棉纺织业迅速崛起, 来自新英格兰乡村和爱尔兰等地的移民构成了洛厄尔多 元的新型工人社区。19 世纪 50 年代, 洛厄尔拥有美国规模最大、最完整的 工业产业链, 成为 “美国工业革命诞生地”。20世纪 20 年代随着美国棉纺 织工业南移, 洛厄尔一度成为 “衰败的工业荒漠”, 城市人口急剧下降, 经 济陷人低谷 ${ }^{[2]}$ 。20 世纪 70 年代, 作为重要的复兴战略, 洛厄尔成为美国国 家公园历史上第一个城市工业遗产地, 基于价值共享理念, 遗产保护带动了 城市空间、经济、文化的全面复兴 ${ }^{[3]}$ 。

\section{1 价值共享机制的形成}

20 世纪 70 年代, 洛厄尔的工业遗产保护面临众多挑战。首先, 城市经 济长期不振, 作为城市支柱的棉纺织业衰败, 失业率维持在 $13 \%$, 居于马萨

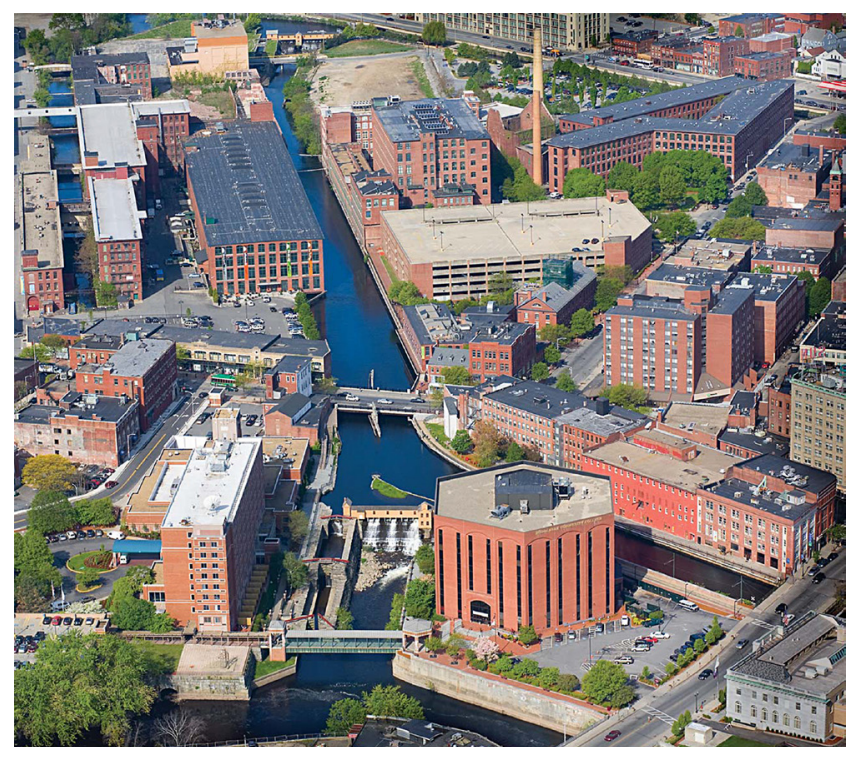

图 1 洛厄尔城市鸟瞰 资料来源 : 参考文献 [4] 


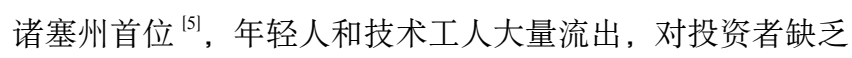
吸引力（图 2)。其次, 民众保护意识淡薄, 面对失业的记 忆, 纺织厂成为大多数人的梦魔, 市议会和政府中许多人希 望抹去这段历史, 工业遗产被看成城市系统的 “负面因素” ${ }^{[5]}$ 。 新老移民构成的多元社区, 对城市遗产漠不关心 ${ }^{[7197-134}$ 。再 次, 工业遗产的状况堪忧。棉纺织厂破产后, 重要工业设施 被废弃、破坏或拆除, 运河水道污染严重, 曾一度计划填埋 ${ }^{[5]}$ 。 洛厄尔的工业遗产保护面临经济、社会动力不足、遗产要素 圆乏的现实问题 ${ }^{[8]}$ 。

城市困局之中, 洛厄尔尝试以遗产价值的共享激发不 同层面的参与, 以遗产保护带动城市经济和社会复兴, 其 目标为：(1) 以多维视角全面挖掘评估工业和城市遗产; (2) 调和多元价值的矛盾冲突, 建立新型合作关系和遗产 管理模式; (3) 以多维阐释激发认同, 以互动的保护利用促 进社会弥合 ${ }^{[5,8]}$ 。

\section{1 价值共享机制的构成}

工业遗产具有多维化的要素构成, 遗产价值与不同受众 关联复杂, 遗产空间可再利用程度高, 遗产时空经验与当代 联系密切等特点, 价值共享机制的关键在于四个方面 : 一是 政策管理机制, 强调以立法与规章确立价值共享的多元合作 框架, 明确各方权责, 保障资金投入和保护利用举措依法合 规、有序安排; 二是要素识别机制, 强调整体化识别, 系统 梳理物质及非物质遗产, 体现多维信息来源和丰富要素构成; 三是价值阐释机制, 强调针对遗产与受众的继承性、相似性、 兴趣性等联系, 以真实性、完整性、包容性及启发性的原则 强化认同, 激发保护参与。四是互动参与机制, 强调通过空 间的共享利用、活动的共同参与强化遗产与当地社区以及其

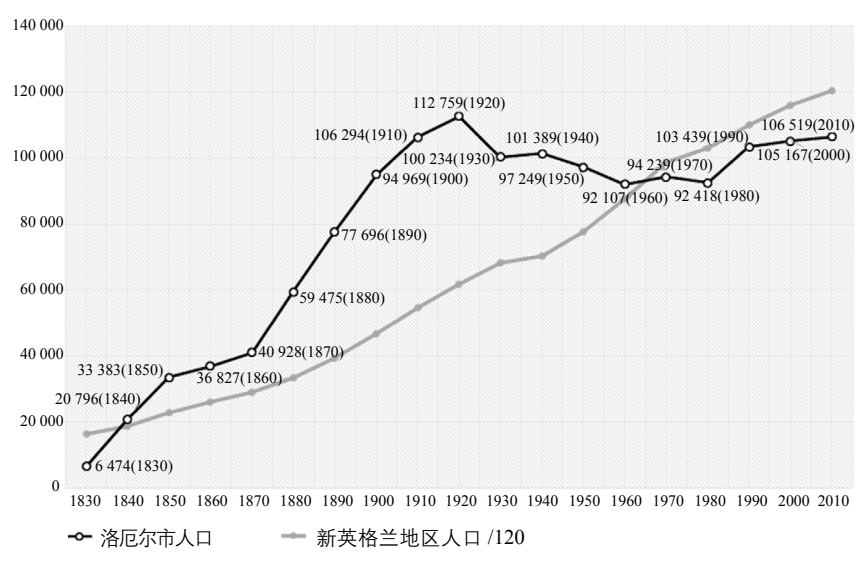

图 2 洛厄尔的人口变化情况 (1830-2010)

资料来源 : 作者根据参考文献 [6] 绘制
他受众的联系, 以遗产实践带动社会弥合和经济复兴。本文 将从这四个方面对洛厄尔的保护实践进行讨论和归纳。

\section{2 洛厄尔国家历史公园的建立}

(1) 地方的保护行动

20 世纪 60 年代末, 主张遗产保护的民间力量以教育家 莫根 (Patrick J. Mogan) 为代表, 认为 “工业和民族遗产是 城市的精神核心, 是拯救城市经济的关键” ${ }^{[8]}$ 。1972 年市议 会开始推动 “历史公园” 概念。两年后, “洛厄尔州立工业 遗产公园” (Lowell Industrial Heritage State Park) 与负责规划、 组织、监管的 “洛厄尔历史运河区委员会” (Lowell Historic Canal Distinct Committee）成立, 成为国家公园的基础 ${ }^{[9]}$ 。

(2) 发展的遗产理念

20 世纪 70 年代, 美国国家公园局（NPS: National Park Service）强调城市格局对于文化的重要性, 开始关注制造业、 科技创新、少数族裔等主题 ${ }^{[101438442}$, 对洛厄尔历史资源的评 估突出了城市整体的价值。洛厄尔作为美国历史上第一个为 制造业规划的城市, 运河、动力设施与产业建筑共同构成了 工业景观, 见证了工业社会的崛起和演变。

(3) 联邦的支持与保障

1978 年, 美国国会正式批准成立洛厄尔国家历史公园 (LNHP: Lowell Naitonal Historic Park) 和洛厄尔历史保护区 (LHPD: Lowell Historic Preservation District), 保护范围包括 作为 “国家历史地标” (National Historical Landmark) 的运 河系统、13 处 “国家历史场所” (National Register of Historic Places) ${ }^{11}$ 以及其他棉纺厂、商业和住宅建筑等, 公园区占 地 $57 \mathrm{hm}^{2}$, 保护区占地 $236 \mathrm{hm}^{2}$ 。同时, 协调各级政府及私 人业主的 “洛厄尔历史保护委员会” (LHPC: Lowell Historic Preservation Commission) 正式建立。作为 NPS 的第一个城 市历史公园, 洛厄尔国家历史公园旨在建立遗产价值的共享 机制, 阐释多维价值, 汇聚保护力量, 拓展社会效益 ${ }^{[5,9]}$ 。

\section{3 保护规划立法}

1978 年以来, 从联邦到地方, 工业遗产确认、保护及管 理的法律及规章相继确立, 遗产清单的完善、多维的阐释与 展示、社区发展与保护并重, 体现着工业遗产基于价值共享 的创新理念 (表 1)。

\section{4 联邦带动、私人主导的投资模式}

1976 年规划建议联邦政府投资总额近 4000 万美元, 其 中 $80 \%$ 作为 NPS 的建设投资, 其余为 LHPC 的保护经费。

(1) 截至 2015 年 1 月, 洛厄尔已有 41 处历史建筑或历史街区列入 “国家历史场所”。 
联邦投资推动了工业遗产保护与利用的进程, 截至 2008 年, 联邦通过 NPS 和 LHPC 的投资达到 6400 万美元, 带动了超 过 5.6 亿的公共及私人投资。NPS 还促成了“美国城市合作 社” (American City Corporation) 10.6亿美元的 “洛厄尔计划” (Lowell Plan), 全面推进城市复兴 ${ }^{[5]}$ 。

为鼓励民间投资，NPS 陆续将园区及洛厄尔保护区的 历史建筑列人 “国家历史场所”, 保护修缮享受减税政策 ${ }^{1}$ 。 在政策刺激下, 大量私人业主和投资商参与到修复项目中, 比如波士顿开发商 “三一金融” 就主导了大型的 “杰克逊 阿普尔顿 - 米德尔塞克斯” (Jackson-Appleton-Middlesex) 工程, 开发商和私人业主的参与, 极大地推动了洛厄尔工业遗产保 护与再利用 ${ }^{[9]}$ (表 2)。

\section{2 挖掘遗产资源 : 整体化识别机制}

洛厄尔基于 “劳动力、技术、资本、自然转变、构建社 区”五个主题, 以丰富的遗产要素、多元化的信息来源、多 维的主题联系形成了价值共享的遗产体系基础（表 3)。

\section{1 物质遗产}

（1）宏观层面：为保护以动力运河为骨架的产业格局, 1974 年前后, 运河填埋计划终止, 运河水质及生态开始逐段 改善 ${ }^{2}$ 。以运河为景观廊道, 工业建筑外立面优先修复。截 至 2012 年, 运河体系已全面恢复, 生态河道、遗产廊道、 水能展道和开发巡道成为生态保护、遗产建筑、水能利用以 及旧城复兴的空间骨架 ${ }^{[12]}$ (图 3, 图 4)。

（2）中观层面：“生产一生活” 体系是工业遗产中极具 特色的功能组团。19 世纪洛厄尔为避免欧洲早期工业城市 拥挤杂乱、疫病高发等问题, 规划厂房与工人住宅, 配建 充足绿地, 这一洛厄尔首创的“生产一生活” 布局, 被 19 世纪 90 年代的城市美化运动所延续 ${ }^{[13]}$ 。以布特棉纺厂为例, 厂房建筑、动力运河河段、工人联排住宅作为一个整体进 行了保护 (图 5)。

(3) 微观层面 : 五个主题下, 对历史建筑及环境要素进 行了完整的梳理, 历史建筑包括工业建筑、商业建筑、市政 公共建筑和住宅四类。历史环境要素包括水坝、水闸、引水渠、

\section{表 1 洛厄尔工业遗产保护的主要法律法规及规划}

\begin{tabular}{|c|c|c|}
\hline 法律、法规及规划 & 时间 & 主要内容 \\
\hline 《国家历史保护法》 & 1966 & 建立 “国家历史场所登录制度”，登录的范围包括工业遗址、工业建筑和工程技术等在内 \\
\hline 《公共法 95-290》 & 1978 & 建立洛厄尔国家历史公园, 以洛厄尔历史保护委员会协调各级政府及私人业主在历史文化资源发展和管理中的作用 \\
\hline 《文化资源清单》 & 1979 & 对洛厄尔公园区和保护区的所有历史建筑物的历史重要性记录建档 \\
\hline 《保护规划细则》 & 1980 & 保护历史资源的操作规划, 提出对纺织复合体、早期居民区的保护, 建议游客中心选址 \\
\hline 《总体管理规划》 & 1981 & 阐释和旅游利用规划，文化资源管理，总体发展计划，合作协定以及技术支持的框架 \\
\hline 《展示说明书》 & 1984 & 确定在展示项目、沽动、水久博物展笕中单䉽洛厄尔上业力史的 5 个王题 \\
\hline 《保护规划修正案》 & 1990 & 增加了运河河直和民间生活的内谷 \\
\hline 《文化资源清单增补》 & 1993 & 确立展示项目的长期规划目标，以公园年工作计划的形式落实 \\
\hline 《综合展示规划》 & 1997 & 明确 LHPC 取消后 LNHP 的角色和责任 \\
\hline 《总体管理规划修正案》 & 2003 & 汉密尔顿运河区的保护发展规划调整 \\
\hline 《总体管理规划修正案》 & 2010 & \\
\hline
\end{tabular}

资料来源 : 作者根据参考文献 [9] 整理

表 2 洛厄尔国家历史公园资金投入（单位：百万美元）

\begin{tabular}{lcccccc}
\hline & NPS & LHPC & 其他联邦投资 & 州投资 & 当地投资 & 私人投资 \\
\hline 1976 年规划 & 31.33 & 8.7 & & & & \\
1992 年规划 (通货膨胀校正) & 77.3 & 21.4 & & & \\
$1978 一 2008$ 年实际投人 & 30.5 & 33.4 & 15.2 & 30.4 & 21.1 & $3.7 \%$ \\
比例 & $5.4 \%$ & $5.9 \%$ & $2.7 \%$ & $5.3 \%$ & $77.0 \%$ & $100.0 \%$ \\
\hline
\end{tabular}

资料来源：作者译自参考文献 [9]

(1) 美国联邦政府于 1976 年取消了拆除旧建筑补贴, 相反, 开始以经济政策鼓励历史建筑遗产的再利用。1978 年的《建筑更新税额抵扣计划》为 历史建筑遗产的修复实行 $10 \%$ 的减税。1 981 年的《经济复兴税收法》规定私人业主对列入 “国家历史场所” 的历史建筑进行保护与修缮, 将 抵扣 $25 \%$ 的税额。其他历史建筑，40 年以上的获 $20 \%$ 投资税减免，30 年以上的获 $15 \%$ 。

(2) 先期恢复的运河包括东运河、梅里马克运河、波塔基特运河、西运河, 汉密尔顿运河的修复正在进行中, 2010 年的总体规划修正案旨在为面 积约 $6 \mathrm{hm}^{2}$ 的汉密尔顿运河区的历史资源保护、环境改善和社区开发提供多情景的实施导则。 


\section{表 3 洛厄尔遗产的五个主题}

\begin{tabular}{|c|c|c|c|}
\hline 主题 & 意义 & 副主题 & 意义 \\
\hline $\begin{array}{l}\text { 劳动力 : 工 } \\
\text { 人及组织 }\end{array}$ & $\begin{array}{l}\text { 家庭小作坊向 } \\
\text { 工厂化生产转 } \\
\text { 变, 社会关系变 } \\
\text { 革, 美国工人阶 } \\
\text { 级崛起 }\end{array}$ & $\begin{array}{l}\text { 女工 } \\
\text { 童工 } \\
\text { 机械男工 } \\
\text { 移民工人 } \\
\text { 工人运动 }\end{array}$ & $\begin{array}{l}\text { 国家历史上第一次由女性主导的工业劳动 } \\
\text { 纺织童工的生活、工作、发展状况具有重要的社会及历史意义 } \\
\text { 工厂组织化的男工主导技术创新、机械维护等关键环节, 体现了机械化生产的特点 } \\
\text { 劳动力中包含了爱尔兰、希腊、波兰、加拿大等国移民, 奠定了多元社会根基 } \\
\text { 工人组织对自动化程度提高、降低工资待遇以及环境变化的应对具有历史意义 }\end{array}$ \\
\hline $\begin{array}{l}\text { 技术 : 工业 } \\
\text { 系统中的工 } \\
\text { 程技术 }\end{array}$ & $\begin{array}{l}\text { 纺织及水利技术 } \\
\text { 进步使洛厄尔成 } \\
\text { 为最重要的工业 } \\
\text { 城市以及棉纺织 } \\
\text { 工业的领航者 }\end{array}$ & $\begin{array}{l}\text { 纺织技术 } \\
\text { 水轮机 } \\
\text { 创新机制 } \\
\text { 建筑技术 }\end{array}$ & $\begin{array}{l}\text { 洛厄尔体系的全套操作工序是美国历史上的首创 ; 实现从原材料到成品的所有工序的整合 ; 见证了美国机械师、 } \\
\text { 优秀工程师的成就以及一系列创新举措 } \\
\text { 本土机械师借鉴法式水轮机原理, 设计了运河水利系统, 奠定了制造业基础 } \\
\text { 洛厄尔的创新推动了棉纺织工业和水利工程进步, 其影响拓展至美国南部及其他地区, 极大地推动了其他地区提 } \\
\text { 升产业竞争力 } \\
\text { 洛厄尔改进建造技术和材料, 形成了棉纺厂具有砖、木、石混合结构的独特风格及布局 }\end{array}$ \\
\hline $\begin{array}{l}\text { 资本 : 市场 } \\
\text { 及经理 }\end{array}$ & $\begin{array}{l}\text { 成功的组织管理 } \\
\text { 经验使洛厄尔成 } \\
\text { 为工业城市建设 } \\
\text { 的样板 }\end{array}$ & $\begin{array}{l}\text { 市场革命 } \\
\text { 利润生产 } \\
\text { 经营工厂 } \\
\text { 产业转移 }\end{array}$ & $\begin{array}{l}\text { 资本家投资运河和道路, 链接产品供应和销售, 建立起地区化市场, 成为最早的市场导向的成熟地区 } \\
\text { 洛厄尔的棉纺织工业的利润率极高, 创造了一种健康的循环经济模式 } \\
\text { 棉纺织经理人及家庭在社会、文化和政治环境中体现重要作用 } \\
\text { 产业南移造成的城市衰退以及产业升级的经验 }\end{array}$ \\
\hline $\begin{array}{l}\text { 自然转变: } \\
\text { 流域水动力 }\end{array}$ & $\begin{array}{l}\text { 水利生产协作与 } \\
\text { 生态意义的重要 } \\
\text { 案例 }\end{array}$ & $\begin{array}{l}\text { 运河动力 } \\
\text { 环境问题 }\end{array}$ & $\begin{array}{l}\text { 纺织协会将流域改造成为高度机械化的水坝、水库和动力运河, 水权可以进行买卖和操作, 水能高效, 反映了一 } \\
\text { 种基于水动力的高度协作的生产组织形式 } \\
\text { 人工改造的运河导致生态群落消失等环境问题, 后期改造是重要的生态修复案例 }\end{array}$ \\
\hline $\begin{array}{l}\text { 构建社区: } \\
\text { 城市化及少 } \\
\text { 数民族文化 }\end{array}$ & $\begin{array}{l}\text { 制造业城市社 } \\
\text { 区的杰出典范, } \\
\text { 移民家庭和多 } \\
\text { 元化民族文化 } \\
\text { 的故乡 }\end{array}$ & $\begin{array}{l}\text { 建造城市 } \\
\text { 公共合作 } \\
\text { 移民文化 } \\
\text { 文化复兴 }\end{array}$ & 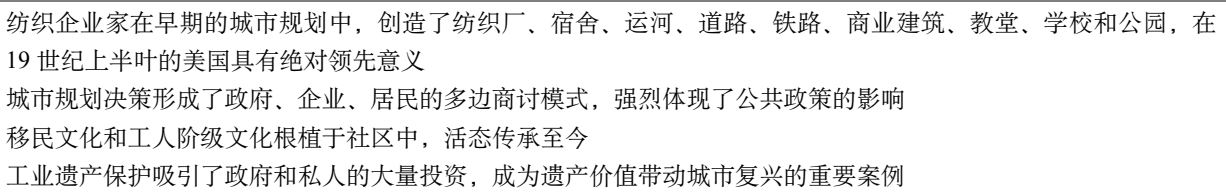 \\
\hline
\end{tabular}

资料来源 : 作者根据参考文献 [11] 整理

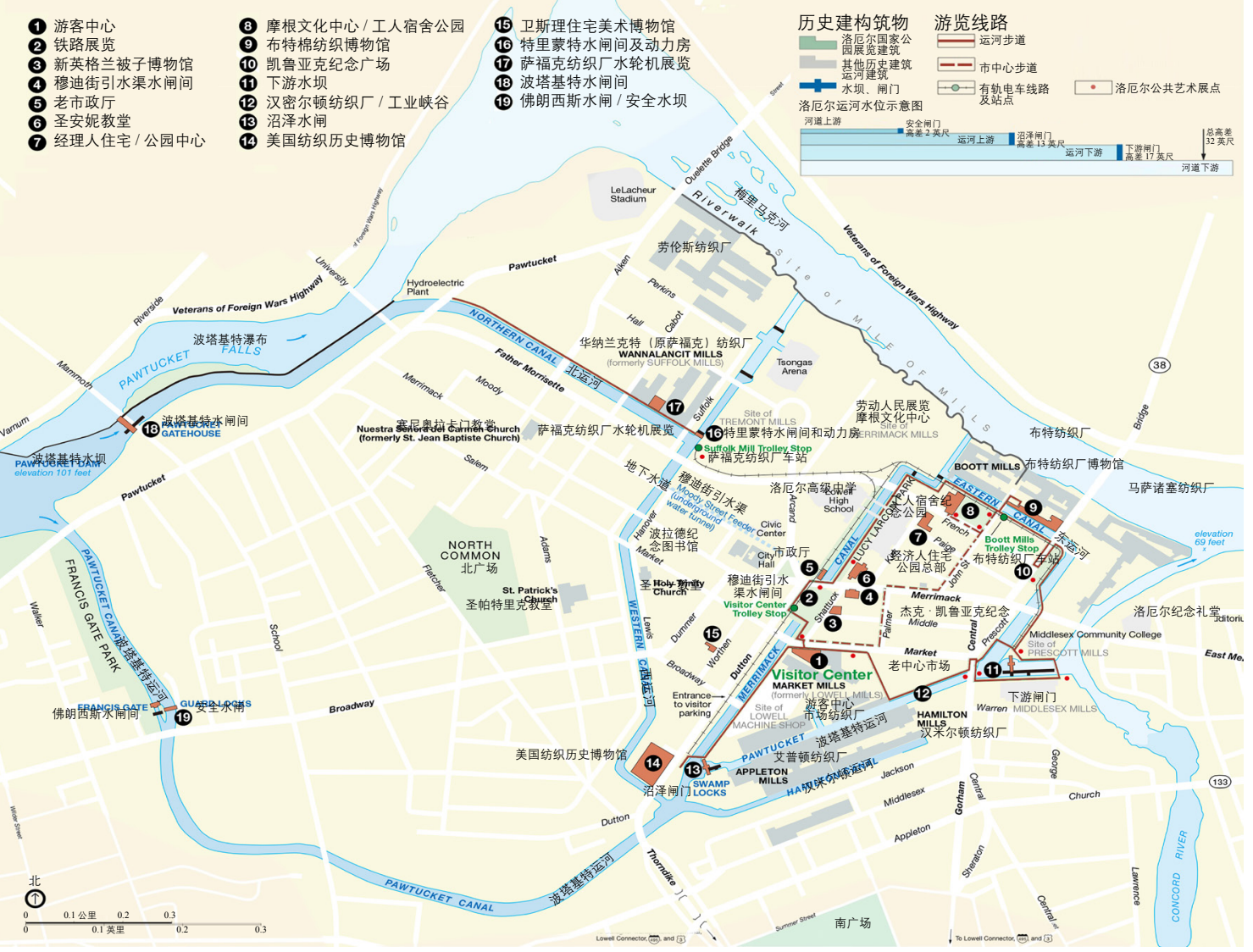

图 3 洛厄尔遗产空间分布图 资料来源：作者根据参考文献 [14] 地图改绘 
动力机械以及工厂的钟楼、吊桥、厂门警卫设施等。国家历 史公园区和保护区共 404 项遗产被评为 $\mathrm{A}$ 级国家历史资源 ${ }^{[5]}$ 。

\section{2 非物质遗产}

多维的非物质遗产强化了价值共享理念。1965 年联邦政 府推动“美国历史建筑普查”(HABS), 开展针对洛厄尔棉 纺织工业遗迹的调查测绘 ${ }^{[10] 438}$ 。1969 年的 “美国历史工程记 录” (HAER) 深人调研了工程建筑物、场地、机械设备、环 境建构筑物和历史档案 ${ }^{1}$ 。地方层面, 由摩根文化中心以及 洛厄尔历史中心发起的 “洛厄尔的过去和今天”，全面搜集 市中心所有历史建筑的历史与演变情况 ${ }^{[11]}$, 为保护提供了丰 富的资料。同时,人类学视角下的美国 “民众史” 著名的“洛 厄尔实验” 影响深远 ${ }^{[7]}$ 。这一思潮下, 民众史资料成为城市 遗产的重要组成。民间组织发挥积极作用, “杰戈逊班克罗 夫特收藏” (The Jeggerson Bancroft collection) 以大量 19 世 纪的信件反映当时的生活情况; “棉纺厂运营信件项目”（Mill Operative Letters Project) 搜集了重要的早期商业记录, 包 括收据、账目、合同等；“水坝运河收藏” (Locks \& Canals Collection）包含大量照片和艺术品等, 为价值共享提供了多 视角的历史资源 ${ }^{[9]}$ 。

\section{3 满足复杂需求 : 多维化的阐释机制}

价值阐释是激发共鸣和保护行动的基础 ${ }^{[16]}$ 。价值共享的 阐释机制不同于一元价值的单一解释, 也不同于多元价值的 对于差异的简单并置, 而是基于受众分析, 设计多维策略, 促进不同人群对于遗产价值的理解、体验与共享。

\section{1 分析遗产与受众的联系}

洛厄尔将当代遗产受众基于地区、年龄、职业、兴趣细
分, 分析受众与遗产间的关联途径, 归纳为三种情况。

（1）继承性：工业遗产与创造者或后代的直接关联, 最 容易产生共鸣。

（2）相似性: 遗产特征与相似背景、事件、人群产生关联, 比如新老移民相似的奋斗经历, 洛厄尔的大萧条与当代金融 危机等。

（3）兴趣性：阐释主题与兴趣专题产生关联, 比如美学 主题、科技主题、多元文化主题等。

\section{2 设计有针对性的阐释策略}

为强化联系、激发共鸣, 洛厄尔设计了针对不同受众的 多维阐释机制。

（1）整合历史资源：洛厄尔将大量分散的物质与非物质 资源进行整合, 塑造具有突出特征的遗产空间。布特棉纺厂 博物馆 (Boott Cotton Mills Museum) 细致完整地还原了棉 纺织工业鼎盛时期的外观及纺织车间, 机械的轰鸣令参观者

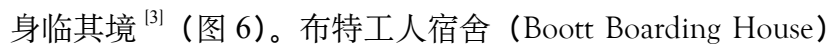
以真实场景和非物质史料展现了多元文化下的居住空间, “劳 动人民：工厂姑娘、移民和劳动者” 的主题陈列, 使观者能 够集中接触到大量遗产信息 ${ }^{[17]}$ 。

（2）展现内在联系 : 洛厄尔注重以联系引发共鸣, 为与 世界不同地区的游客共享, 洛厄尔被置于工业全球化图景之 中一一肇始于英国德温特谷部, 并在中国大陆、越南及其他 地区延续的工业发展脉络 ${ }^{[5]}$; 为与不同年龄的受众共享, 展 示不同年代的生活场景, 比如通过串联著名作家杰克 - 凯鲁 亚克的相关场所, 反映美国战后一代的生活风貌, 使人们易 于从经历中找到相似点, 产生共鸣 ${ }^{[17]}$ 。

（3）挖掘兴趣专题: 洛厄尔注重在阐释中组织不同的主 题, 多元社会主题, 深人揭示了社区的构成演变及其对当代

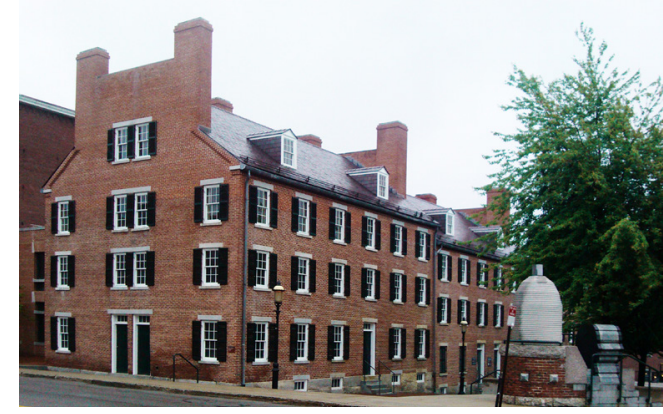

图 5 修复后的女工宿舍, 现为摩根文化中心 资料来源 : 作者拍摄

(1)《美国历史工程记录历史建构筑物与场地的记录》(Recording Historic Structures and Sites for the Historic American Engineering Record) 规定报告 内容包含：(1) 场地评估：场地、构筑物、工作场地、技术变革和影响力分析等。(2) 历史报告：介绍、照片、测绘图、文字现场报告等。 （3）照片：档案加工、技术信息、场景照片等。(4) 测绘图：规划、现场作业、现场记录、现场摄影、记录与摄影的提交等 ${ }^{[15]}$ 。 


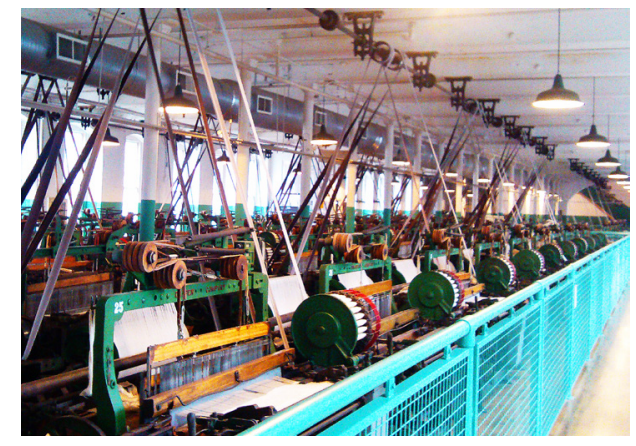

图 6 纺织车间正在运作的纺织机 资料来源 : 作者拍摄
的影响; 科技创新主题, 展现了水利和机械技术的创新, 并 与当今纺织科技、机械革新生动联系; 生态保护主题, 包含 了河道修复的环境治理和再生循环技术, 使不同兴趣的人们 都能够探索和理解洛厄尔的遗产价值。

\section{3 遵循价值共享的阐释原则}

洛厄尔的遗产阐释机制强调以价值共享的理念调和多元 价值的冲突（表 4)，其原则包括以下几点。

（1）真实性原则，强调信息来源及阐释策略的真实性, 强化真实的场所体验。

\section{表 4 洛厄尔遗产资源的阐释策略与遗产受众}

\begin{tabular}{|c|c|c|c|c|c|}
\hline 代表遗产资源 & 保护利用与阐释策略 & 主题 & 相关性 & \multicolumn{2}{|c|}{ 当代遗产受众 } \\
\hline $\begin{array}{l}\text { 市场纺织厂 } \\
\text { (Market Mills) } \\
\text { 布特棉纺厂 } \\
\text { (Boott Cotton Mills) } \\
\\
\text { 萨福克纺织厂 } \\
\text { (Suffolk Mills) }\end{array}$ & $\begin{array}{l}\text { 修复后底层作为国家历史公园游客中心 } \\
\text { 二层以上改造为家庭及老年公寓 } \\
\text { 国家公园信息中心及洛厄尔文化活动信息中心 } \\
\text { 多媒体、场景及实物展陈 “洛厄尔: 美国工业之思” } \\
\text { 运河游、电车游等专题旅游路线的出发地 } \\
\text { 修复建筑外观、工厂庭院、河道环境及沿河步道 } \\
\text { 复原生产车间、活态展示 } 19 \text { 世纪棉纺织全流程 } \\
\text { 互动展示纺织原理及工业城市起源 } \\
\text { 布特棉纺厂博物馆 (Boott Cotton Mills Museum) } \\
\text { 联格斯工业历史中心 (Tsongas Industrial History Centre) } \\
\text { 修复建筑外观及运河动力设施 } \\
\text { 复原水轮机带动纺织机械工作场景 } \\
\text { 全面展现工业生产中的声热湿味等环境特征 } \\
\text { 萨福克纺织厂水轮机展览 (Suffolk Mills Turbine Exibit) }\end{array}$ & $\begin{array}{l}\text { 纺织厂 } \\
\text { 纺织工业 } \\
\text { 城市化 } \\
\text { 多媒体 } \\
\text { 住宅补贴 } \\
\text { 工人资本 } \\
\text { 工人生产 } \\
\text { 纺织技术 } \\
\text { 工业化 } \\
\text { 互动参与 } \\
\text { 机械 } \\
\text { 工人 } \\
\text { 工厂生产 } \\
\text { 运河动力 }\end{array}$ & & $\begin{array}{l}19 \text { 世纪移民 } \\
\text { 后 代（爱尔 } \\
\text { 兰、希腊、加 } \\
\text { 拿大等） } \\
20 \text { 世纪新移 } \\
\text { 民（拉丁美 } \\
\text { 洲、亚洲等） } \\
\text { 本国 } \\
\text { 国外 }\end{array}$ & $\begin{array}{l}\text { 不 } \\
\text { 同 } \\
\text { 地 } \\
\text { 区 }\end{array}$ \\
\hline $\begin{array}{l}\text { 工人宿舍 } \\
\text { (Boardinghouse) } \\
\text { 柯克街经理住宅 } \\
\text { (Kirk Street agent's House) } \\
\text { 卫斯理住宅 } \\
\text { (Whisler House) }\end{array}$ & $\begin{array}{l}\text { 修复联排住宅外观 } \\
\text { 复原工人宿舍内部场景 } \\
\text { 固定展陈“劳动工人展” “美国工人故事”多媒体展示 } \\
\text { 摩根文化中心 (Mogan Coltural Center) } \\
\text { 洛厄尔历史中心 (Centre for Lowell History) } \\
\text { 保护纺织厂经理的住宅的外观 } \\
\text { 场景展示维多利亚式上层阶级的生活景象 } \\
\text { 展示棉纺织工业发展中经理人的作用 } \\
\text { 保护建筑外观及基本功能 } \\
\text { 内部改造为艺术家居住及创作空间及画廊 } \\
\text { 卫斯理住宅（Whisler House Museum of Art） }\end{array}$ & $\begin{array}{l}\text { 女工 } \\
\text { 移民 } \\
\text { 生活场景 } \\
\text { 多元文化 } \\
\text { 志愿者 } \\
\text { 上层阶级 } \\
\text { 工厂管理 } \\
\text { 艺术风格 } \\
\text { 绘画艺术 } \\
\text { 历史住宅 } \\
\text { 中产阶级 }\end{array}$ & & $\begin{array}{l}\text { 学龄前儿童 } \\
\text { 中小学生 } \\
\text { 大学生 } \\
\text { 成年人 } \\
\text { 老年人 }\end{array}$ & $\begin{array}{l}\text { 不 } \\
\text { 同 } \\
\text { 年 } \\
\text { 龄 }\end{array}$ \\
\hline $\begin{array}{l}\text { 基特森商店 } \\
\text { (Kitson House) } \\
\text { 麦克建筑 } \\
\text { (Mack Building) } \\
\text { 圣安妮教堂 } \\
\text { (St. Anne's Church) }\end{array}$ & $\begin{array}{l}\text { 外观修复, 内部改造为永久展陈空间 } \\
\text { 收集早期纺织业手工工具及作品 } \\
\text { 实物展陈、场景展陈、多媒体展陈、互动展陈 } \\
\text { 美国纺织历史博物馆（American Textile History Museum） } \\
\text { 修复 } 19 \text { 世纪的商业建筑外观 } \\
\text { 新英格兰被子博物馆（New England Quilt Museum） } \\
\text { 保护 } 19 \text { 世纪工人教堂外观, 局部整修 } \\
\text { 维持原先用途 }\end{array}$ & $\begin{array}{l}\text { 纺织工业 } \\
\text { 全产业链 } \\
\text { 艺术风格 } \\
\text { 互动参与 } \\
\text { 多媒体 } \\
\text { 商业建筑 } \\
\text { 艺术风格 } \\
\text { 社区展览 } \\
\text { 多元文化 } \\
\text { 民间信仰 }\end{array}$ & & $\begin{array}{l}\text { 工人及劳工组 } \\
\text { 织 } \\
\text { 企业家 } \\
\text { 农业相关者 } \\
\text { 城市管理者 } \\
\text { 艺术家 }\end{array}$ & $\begin{array}{l}\text { 不 } \\
\text { 同 } \\
\text { 职 } \\
\text { 业 }\end{array}$ \\
\hline $\begin{array}{l}\text { 市民广场 } \\
\text { (Boardinghouse Park) } \\
\text { 火车轨道 } \\
\text { (Railway Trail) } \\
\text { 运河体系 } \\
\text { (Canal System) }\end{array}$ & $\begin{array}{l}\text { 保护宿舍前广场历史环境要素 } \\
\text { 示意曾经的纺织厂建筑的钢结构作为露天舞台 } \\
\text { 举办洛厄尔民间文化节、音乐节等活动 } \\
\text { 回复历史环境要素, 复原 } 19 \text { 世纪火车轨道场景 } \\
\text { 复原 } 19 \text { 世纪街景, 场景展示 } \\
\text { 火车展览 (Railroad Exhibit) } \\
\text { 修复波塔基特、梅里马克、汉密尔顿、东、西、北运河及 } \\
\text { 地下引水渠 } \\
\text { 修复或重建水坝、水闸间及其他运河动力设施 } \\
\text { 修复运河景观廊道两侧建筑外立面及生态植被 } \\
\text { 专题展示运河动力、防洪设施及水权控制 }\end{array}$ & $\begin{array}{l}\text { 民族文化 } \\
\text { 社区庆典 } \\
\text { 互动参与 } \\
\text { 运输 } \\
\text { 城市化 } \\
\text { 市场贸易 } \\
\text { 水能 } \\
\text { 防洪 } \\
\text { 生态 } \\
\text { 水权控制 } \\
\text { 景观廊道 }\end{array}$ & & $\begin{array}{l}\text { 历史纪念 } \\
\text { 艺术审美 } \\
\text { 科学技术 } \\
\text { 工业化 } \\
\text { 城市发展 } \\
\text { 多元文化 }\end{array}$ & \\
\hline
\end{tabular}

资料来源 : 作者根据参考文献 $[2,5,9,11]$ 内容整理 
（2）完整性原则，整合分散的历史资源，以系统化的遗 产信息满足差异化的需求。

（3）包容性原则。客观中立的展现多维的遗产价值, 避 免一元立场的封闭性。

（4）启示性原则。注重引导思考, 启发借鉴时空经验, 消除误解, 建立地方认同。

\section{4 拓展社会效益 : 互动化的保护利用机制}

\section{1 遗产空间共享利用}

政府、企业与居民共同承担遗产空间的保护成本，共享 遗产价值。洛厄尔 $293 \mathrm{hm}^{2}$ 的公园区及保护区中, 联邦持有 的仅有 $4.3 \mathrm{hm}^{2}$ 。通过示范和市场引导, 遗产空间再利用实现 了功能混合与居住混合（图 7)。以市场纺织厂复合体（Market Mill Complex）为例, 两栋分别建成于 1882 年和 1902 年的 建筑于 1980 年被火灾损毁后, LHPC 将底层的 $3900 \mathrm{~m}^{2}$ 改 造为 LNHP 游客中心, 开发商市场纺织厂协会 (Market Mills Associates）将上层改造为 230 套家庭及老年住宅, 项目于 1982 年完成 ${ }^{[9]}$ 。目前, 48.3 万 $\mathrm{m}^{2}$ 的棉纺厂已有 $94 \%$ 修复后 以住宅、办公、展览空间等方式再利用 ${ }^{[19]}$, 包括 $10 \%$ 的可支 付住宅和政府补贴住宅, 实现了遗产空间的共享利用。

\section{2 遗产活动共享参与}

关注社区建设的遗产活动, 成为联系居民与遗产、居民 与社区的纽带。

（1）连接多元社会: 遗产实践体现了对不同文化的包容。 “社区参与计划”和民间文化节尊重不同族裔传统、文化和 历史, 鼓励居民参与到遗产保护、阐释、教育活动当中 ${ }^{[12]}$ 。 历史遗产中多元社区的经验也促进了地区认同和社区弥合。

（2）开展遗产教育：遗产教育成为代际交流的桥梁。聪 格斯工业历史中心鼓励青少年从历史中学习科学、技术、工 程及数学知识, 每年多达 5 万学生参与 ${ }^{[18]}$ 。“社区下一代” 开 展“纺织城市”、“社区团队”、“环境友好国家公园”等宣传 教育项目, 激发青少年对家乡的认同和对工业遗产的继承 ${ }^{[12]}$ 。

（3）开放遗产文化：当地居民可以通过开源方式 “维基 诠释”, 参与搜集历史资源, 解读城市遗产。居民也能以志 愿者的身份加人保护实践, 每年居民的累积志愿时长近十万 小时 ${ }^{[20]}$ 。这些文化活动强化了居民和遗产的联系, 也突出了 共享机制对于城市遗产文化的影响。

\section{3 遗产经济拉动城市复兴}

工业遗产的保护与利用振兴了洛厄尔的经济。截至 2014

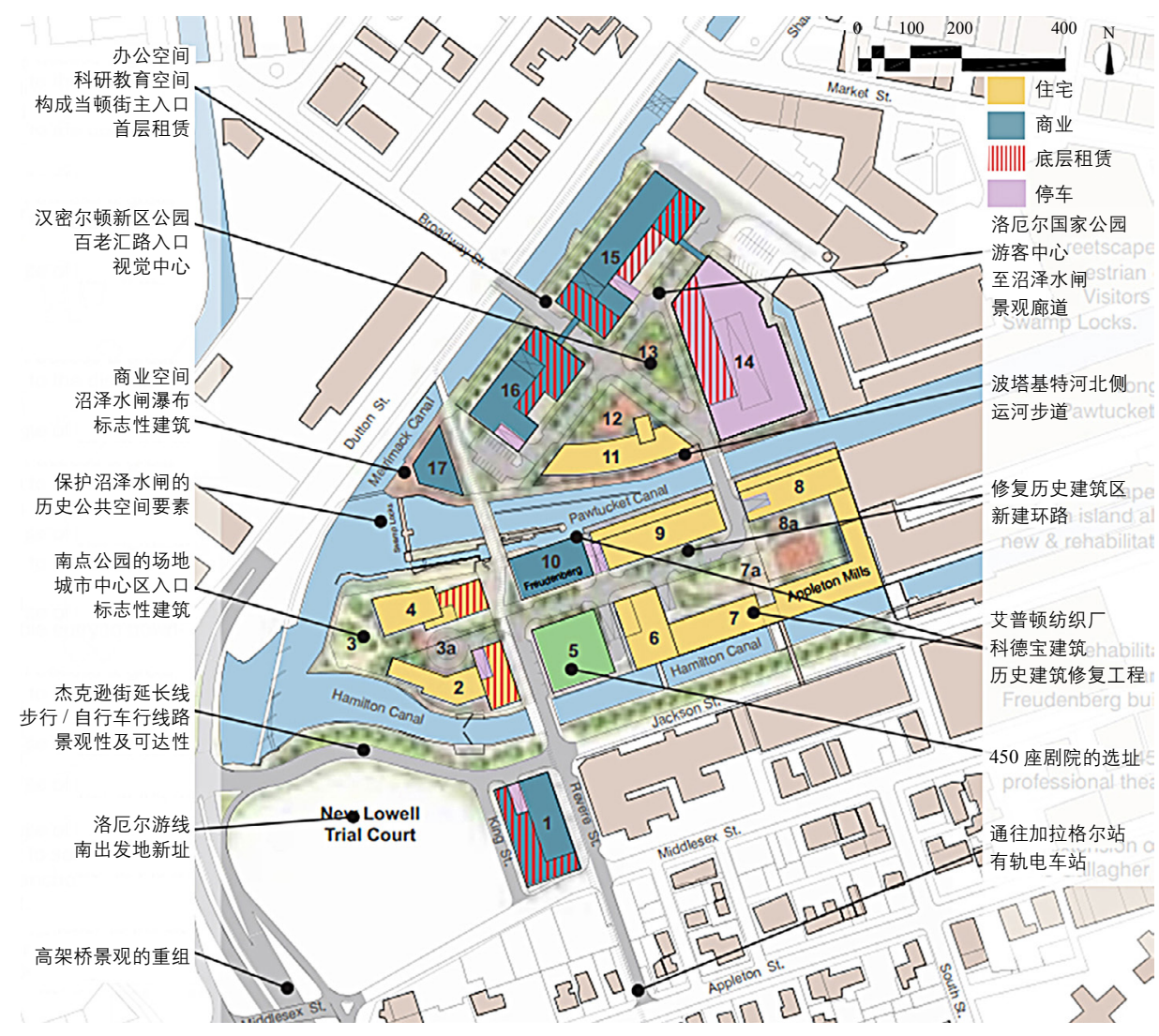

图 7 汉密尔顿运河区功能混合的修复利用规划 资料来源 : 作者根据参考文献 [18] 改绘 
年, 洛厄尔游客访问量为 2076 万人次, 人均接待游客数超 过地区中心波士顿 ${ }^{[21]}$ 。以 2013 年为例, 洛厄尔国家公园的 访问量为 51.8 万人次, 其中非当地游客 43.5 万人次, 旅游业 直接收人 2853.9 万美元, 创造 387 个就业岗位, 为居民创收 1486.3 万美元, 产业附加值 2406.1 万美元, 总产出 3792.4 万美元 ${ }^{[22]}$ 。工业遗产旅游带动了当地旅馆、民宿、餐饮、 交通业的发展, 同时吸引了对于当地环境改善及基础设施 建设的投资，作为 “新英格兰奇迹” 的王恩实验室 (Wang Laboratories) 迁址于此 ${ }^{[2]}$ 。城市中心区活力提升, 人口密度 较 20 世纪 70 年代提升 $512 \%$ 。

\section{5 对我国工业遗产保护的启示}

笔者认为, 洛厄尔的工业遗产价值共享机制实践, 对我 国的工业遗产保护有四点启发。

（1）应建立共享实践的多边合作框架。目前我国的遗产 实践还多由政府推进, 多边合作机制不健全, 亟需建立政府、 咨询机构、地方企业、保护团体、社区居民等利益相关方的 多边合作框架, 明确保护目标、各方权责以及阶段性任务。 洛厄尔以 NPS 提供遗产管理技术咨询, 联邦政府推动核心 项目, 私人业主在规范下参与遗产开发, 开放平台确保日常 监督的合作框架具有借鉴意义。

(2) 应完善工业遗产的整体化识别机制。我国对于工业 遗产的多维要素构成认识还不充分, 难免造成载体破碎化、 片段化的现象。洛厄尔以主题串联, 强化整体化识别机制, 物质素材与非物质素材系统化的遗产资源体系契合了当代多 元关注点与多维需求层次。整体化识别使多元的历史资源不 是简单并置, 而是基于丰富的细节呈现立体相关性, 是遗产 价值共享的基础。

（3）应设计多维共享的价值阐释策略。随着我国公民认 知能力的提高, 单一维度的遗产阐释无法满足需要。以洛厄 尔为例, 如果将某一阶层的利益作为价值判断的标准, 必然 会使其他人漠视甚至排斥遗产实践。多元社会中必须树立价 值共享的观念, 设计具有包容性和启发性的多维阐释策略, 使遗产价值既易于被不同受众认知, 又引导人们深人思考现 实问题, 增进不同人群间的相互理解。

（4）应倡导互动共享的遗产保护利用。我国的工业遗产 再利用中, 常常出现单一文化旅游功能或是绅士化的现象, 造成遗产实践参与性差、认同度不高, 可持续性不足的情况。 遗产利用应考虑到不同社会阶层的需求, 不仅服务旅游业, 还应满足当地民众的现实需要; 除提供文化产品外, 还应关 注到弥合社区、代际交流的作用。通过阶层混合、共同参与 的保护利用, 调动不同阶层的积极性, 使工业遗产真正成为 整个社会的共同财富。UPI
论文得到清华大学张杰教授的多次指导, 特此致谢。

\section{参考文献}

[1] Lowell City Council. Sustainable Lowell 2025 Master Plan[EB/OL]. [201402-01]. http://www.lowellma.gov/dpd/devservices/Documents/Land\%20 Board\%20Regulations/Final\%20Master\%20Plan.pdf.

[2] Dublin T. Lowell: The Story of an Industrial City: A Guide to Lowell National Historical Park and Lowell Heritage State Park, Lowell, Massachusetts[M]. Government Printing Office, 1992.

[3] Thomas E Leary, Elizabeth C Sholes. Authenticity of Place and Voice: Examples of Industrial Heritage Preservation and Interpretation in the U.S. and Europe[J]. The Public Historian, 2000: 49-66.

[4] Lowell National Historical Park. Annual Report 2009[R]. National Park Service, 2010.

[5] Dennis Frenchman, Jonathan S Lane. Discussion White Paper Assessment of Preservation and Development in Lowell National Historical Park at its 30-Year Anniversary[R]. National Park Service, 2008.

[6] United States Census Records and Population Estimates Program. Lowell Historic Population[DB/OL]. [2014-12-22]. http://en.wikipedia.org/wiki/ Lowell,_Massachusetts.

[7] Cathy Stanton. The Lowell Experiment: Public History in a Postindustrial City[M]. University of Massachusetts Press, 2006.

[8] Brian C Mitchell. Interpreting American Industrial History: The Lowell National Historical Park's General Management Plan: An Overview[J]. International Labor and Working-Class History, 1982(Spring): 69-72.

[9] Lowell National Historical Park. Lowell National Historical Park: General Management Plan Amendment \& Environmental Assessment[Z]. National Park Service, 2010

[10] John H Stubbs, Emily G Makaš. Architectural Conservation in Europe and the Americas[M]. New Jersey: John Wiley \& Sons, 2011.

[11] Lowell National Historical Park. Long Range Interpretive Plan[Z]. National Park Service, 2010.

[12] Lowell National Historical Park. Annual Report 2012-2013[R]. National Park Service, 2013.

[13] Mary C Beaudry. The Lowell Boott Mills Complex and Its Housing: Material Expressions of Corporate Ideology[J]. Historical Archaeology, 1989, 23(1): 19. 32.

[14] Lowell National Historical Park. Map of Lowell National Historical Park[DB/OL]. [2014-12-01]. http://www.nps.gov/lowe/planyourvisit/ upload/LOWEmap $1^{[1]}$.pdf.

[15] National Park Service. Secretary of the Interior's Standards and Guidelines for Architectural and Engineering Documentation[EB/OL]. [2015-02-01]. http://www.cr.nps.gov/hahshaer/pubs/sisgaed.pdf.

[16] Tilden F. Interpreting Our Heritage[M]. University of North Carolina Press, 1957: 8 .

[17] Carolyn M Goldstein. Many Voices, True Stories, and the Experiences We Are Creating in Industrial History Museums: Reinterpreting Lowell, Massachusetts[J]. The Public Historian, 2000(Summer): 129-137.

[18] Trinity Financial \& ICON Architecture. Hamilton Canal District Master Plan[Z]. 2008.

[19] Lowell National Historical Park. Annual Report 2013-2014[R]. National Park Service, 2014.

[20] Lowell National Historical Park. Annual Report 2011-2012[R]. National Park Service, 2012.

[21] National Park Service. Annual Park Recreation Visitation[DB/OL]. [201412-01]. https://irma.nps.gov/Stats/Reports/Park.

[22] National Park Service. 2013 National Park Visitor Spending Effects: Economic Contributions to Local Communities, States, and the Nation[R]. 2014.

(本文编辑：许玫) 